Jakub Synowiec

Uniwersytet Papieski Jana Pawła II w Krakowie

ORCID: 0000-0002-6357-6344, e-mail: jakub.synowiec@upjp2.edu.pl

https://doi.org/10.4467/25443283SYM.20.018.12949

\title{
CHRZEŚCIJAŃSKIE UJĘCIE RELACJI CZŁOWIEKA DO STWORZENIA W OPARCIU O METAFORĘ DIALOGU
}

\section{CHRISTIAN APPROACH TO RELATION BETWEEN MAN AND CREATION ON THE BASIS OF THE METAPHOR OF DIALOGUE}

\begin{abstract}
Abstrakt
W artykule wykorzystano metaforę dialogu w celu naświetlenia chrześcijańskiego ujęcia relacji człowieka do stworzenia. Metafora dialogu została zbudowana w oparciu o koncepcję dialogu z Nowej dialektyki D. N. Waltona. Artykuł podzielony jest na trzy części, w których omówione są wybrane cechy dialogu oraz odniesione do nich chrześcijańskie ujęcie relacji człowiek - stworzenie: wspólny cel uczestników dialogu, wymóg znajomości partnera w dialogu i efekt dialogu wynikający z jego natury, a więc porozumienie. W konkluzjach przedstawiona została koncepcja ekologii ludzkiej, podkreślono liczne podobieństwa między chrześcijańską i niechrześcijańską myślą ekologiczną i zidentyfikowano, dlaczego dialog chrześcijaństwa ze stworzeniem nie funkcjonuje tak, jak w świetle nauczania Kościoła powinien.
\end{abstract}

Słowa kluczowe: ekologia, stworzenie, dialog, Laudato si' 


\section{Abstract}

The article uses the metaphor of dialogue to illuminate the Christian approach to the relationship of man to creation. The metaphor of dialogue is shaped on the basis of the concept of dialogue from $\mathrm{D}$. N. Walton's The New Dialectic. The article is divided into three parts, in which selected features of dialogue are discussed to throw light on the Christian approach to the human-creation relationship related to them: the common goal of the participants in the dialogue, the requirement to know the partner in the dialogue and the result of dialogue resulting from its nature, i.e. agreement. The conclusions present the concept of human ecology, emphasize numerous similarities between Christian and non-Christian ecological thought, and identify why Christian dialogue with creation does not function as it should in the light of the Church's teaching.

Keywords: ecology, creation, dialogue, Laudato si'

W artykule wykorzystuję metaforę dialogu, aby przez jej pryzmat przyjrzeć się relacji człowieka z przyrodą w ujęciu chrześcijańskim. Pojęcie dialogu czerpię z nowej dialektyki Douglasa N. Waltona. Opisując chrześcijańskie spojrzenie na relację człowieka z przyrodą, opieram się na filozoficzno-teologicznej argumentacji zawartej w katolickiej nauce społecznej - w tym szczególnie w encyklice papieża Franciszka Laudato si' - oraz na badaniach wybranych autorów reprezentujących filozofię chrześcijańską i teologię katolicką. Wydaje się, że metafora dialogu jest w odniesieniu do relacji człowiek - stworzenie ciekawym narzędziem heurystycznym, pozwalającym zidentyfikować główną przyczynę braku postępu w relacji człowiek - stworzenie.

Dialog, nawet w potocznym rozumieniu, słusznie kojarzy się nam $\mathrm{z}$ rozmową dwóch osób i w związku z tym nie pasuje jako narzędzie do opisu relacji człowieka ze światem stworzonym. Rozumienie dialogu jako relacji międzyludzkiej ma filozoficzne uzasadnienie i ponad 2000 lat tradycji. Najbardziej znany polski filozof dialogu ks. Józef Tischner mówi o związku dialogicznym jedynie w relacji człowiek - człowiek. Świat to dla niego materialny substrat sceny, na której rozgrywa się dramat. Scena zaś nie przesądza w żaden sposób o dramacie ludzkim - to rodzaj obiek- 
tywności ontycznej, jest materialna, realna i potrzebna, to w niej ujawnia się dobro i zło. Jednakże w dialog się z nią nie wchodzi ${ }^{1}$. Rozważania ks. Tischnera mają charakter antropologiczny. Warto mieć to na uwadze, bowiem używanie do opisania relacji człowiek - stworzenie pojęć właściwych relacjom międzyludzkim grozi antropomorfizacją przyrody, a w dalszej kolejności wyciąganiem nieuprawnionych wniosków. Unikamy tego, pamiętając, że chodzi tylko o metaforę.

$\mathrm{Na}$ potrzeby metafory proponuję przyjąć definicję dialogu z teorii argumentacji z Nowej dialektyki. Tutaj dialog jest rozumiany jako „normatywne ramy, w ramach których zachodzi wymiana pomiędzy dwoma partnerami rozmowy, którzy razem rozumują w celu osiągnięcia wspólnego celu"2. Oczywiście również w tym ujęciu stworzenie nie może być, w sensie dosłownym, partnerem dialogu. Wydaje się jednak, że użycie pojęcia dialogu zaczerpniętego $\mathrm{z}$ teorii argumentacji jako pewnej metafory do opisania relacji człowiek - stworzenie jest narzędziem bardzo płodnym heurystycznie.

\section{Wspólny cel dialogu człowieka ze stworzeniem}

Twórca Nowej dialektyki, Douglas N. Walton, określa rodzaj dialogu po wspólnym celu, jaki mają dialogujące ze sobą strony ${ }^{3}$. Jaki jest wspólny cel dialogu człowieka i stworzenia? Antropologia chrześcijańska mówi o różnych celach, które można by tu brać pod uwagę: o nadprzyrodzonym (ostatecznym) celu człowieka, tj. zbawieniu, oraz o celach doczesnych, które temu nadprzyrodzonemu służą. Pośród tych celów doczesnych jest prawda. Prawda o stworzeniu jest nam bardzo potrzebna i wiąże się z realizacją celu nadprzyrodzonego! Jednak - jak zwraca uwagę

${ }^{1}$ Zob. W. P. GLInkowski, Problem sceny w Tischnerowskiej filozofii dramatu, „Analiza i Egzystencja” 34 (2016), s. 71-90.

2 "A dialogue is defined as a normative framework in which there is an exchange of arguments between two speech partner reasoning togetaher in turn-taking sequence aimed at a collective goal". Tłum. własne - J. Synowiec, w: D. N. WaLton, The New Dialectic. Conversational contexts of argument, Toronto - Buffalo - London 1998, s. 30.

${ }^{3}$ Por. tamże. 
papież Franciszek - człowiek nie jest ostatecznym celem dla wszystkich innych stworzeń. Raczej trzeba mówić o wspólnym celu, ostatecznym kresie w Bogu. Rola człowieka jest tu jednak wyjątkowa, tylko on może mieć świadomość celu. Franciszek pisze: „człowiek, obdarzony inteligencją i miłością, pociągany jest pełnią Chrystusa, powołany jest, by przyprowadzić wszystkie stworzenia do ich Stwórcy"4. Krótka refleksja nad wspólnym celem człowieka i stworzenia pokazuje jego odpowiedzialne zadanie. Jak miałby je jednak wypełnić?

Pozwolę sobie na kolejną metaforę. Wyobraźmy sobie jeden z pięknych ogrodów, np. ten przy klasztorze księży sercanów w Stadnikach. Rosną tam piękne magnolie. Magnolia nie jest gatunkiem rodzimym, jej hodowla, a zwłaszcza utrzymanie w dobrej kondycji wymaga pewnego wysiłku. Dlaczego te magnolie tak pięknie rosną? Ponieważ osoba, która się nimi zajmuje, wie, czego im potrzeba, a więc zna prawdę o magnoliach. Wiedziała, gdzie je posadzić i jak je pielęgnować. Ta wiedza i oddanie znamionują dobrego ogrodnika. Przy okazji metafory magnolii warto dodać, że magnolia, czy w ogóle drzewo, przeżywa jednego ogrodnika; sadził dziadek, pielęgnują dzieci, wnuki... Drzew nie sadzi się tylko dla siebie, ale i dla tych, którzy przyjdą po nas i co do których nie mamy nawet pewności, jacy będą, ale wiemy, że też potrzebują ogrodu. Dobry ogrodnik ma świadomość, że uczestniczy w czymś większym od siebie. Jeżeli ogrodnik zniszczy ogród czy podporządkuje go swoim krótkowzrocznym celom, historia ogrodu może się zakończyć.

Poznawanie prawdy o stworzeniu jest naszym zadaniem; koniecznym, żebyśmy mogli - jak pisał św. Jan Paweł II - wypełniać powinność człowieka względem stworzenia zapisaną w Księdze Rodzaju ${ }^{5}$, czyli

${ }^{4}$ Franciszek, Encyklika Laudato si', Rzym 2015 (dalej: LS), 83.

5 „Człowiek zdaje się często nie dostrzegać innych znaczeń swego naturalnego środowiska, jak tylko te, które służą celom doraźnego użycia i zużycia. Tymczasem Stwórca chciał, aby człowiek obcował z przyrodą jako jej rozumny i szlachetny «pan» i «stróż», a nie jako bezwzględny «eksploatator»”. JAN PAWEŁ II, Encyklika Redemptor hominis, Rzym 1979, 15. Fragment ten objaśnia S. Jaromi: „Człowiek jest wezwany do współpracy z Bogiem po to, aby stan naszej planety odpowiadał planom Bożym i by była ona przyjaznym środowiskiem dla wszystkich form życia: roślin, zwierząt i przede wszystkim dla niego samego - człowieka. Ten ludzki wysiłek odkrycia praw rządzących przyrodą jest - we- 
uprawianie i doglądanie ogrodu świata, a więc według papieża Franciszka: oranie, kultywowanie, chronienie, strzeżenie, zachowanie, bronienie, czuwanie, zapewnienie, by ziemia była płodna dla przyszłych pokoleń ${ }^{6}$. Umieszczenie człowieka w nowo stworzonym ogrodzie odzwierciedla według Franciszka - Boży zamysł: człowiek nie tylko ma pielęgnować ogród i troszczyć się o niego, ale też uprawiać go i to tak, żeby przynosił on owoce ${ }^{7}$. Oto zadania ogrodnika stworzenia.

Z praktyki życia wiemy, że dobry ogrodnik musi posiadać wiedzę o roślinach i o tym, co zrobić, żeby one się rozwijały, a ogród kwitł, dawał owoce i nie niszczał. Dobry ogrodnik musi zatem być... ekologiem ${ }^{8}$ (ekologia w sensie ścisłym bada oddziaływania między organizmami żywymi a środowiskiem, $\mathrm{z}$ ochroną środowiska jest utożsamiana w rozumieniu potocznym ${ }^{9}$ ). Wtedy też będzie wiedział, jak korzystać z dóbr ogrodu, żeby go nie zniszczyć. Jednak ogrodnik w pewnym sensie ogrodowi służy, musi być bowiem gotów do poświęceń na jego rzecz. Sianie, sadzenie, przycinanie, zbiory - to wszystko ma swój rytm i ten rytm trzeba przedłożyć nad swoje pragnienia. Wydaje się, że to są bezinteresowne wyrzeczenia oraz wielkoduszne gesty wobec świata, do których wzywa papież Franciszek w Laudato si', gdy mówi o ekologicznym nawróceniu! ${ }^{10}$.

Ogrodnik musi pamiętać, że jest ogrodnikiem, w pewnym sensie piastunem powierzonych dóbr, a nie właścicielem. Właściciel potem ogrodnika z pracy rozliczy. W ten sposób cel doczesny łączy się z nadprzyrodzonym. Bez celu nadprzyrodzonego mamy relację z przyrodą nastawioną na samą prawdę. Wiedza zaspokoi naszą ciekawość, ale to jest za mało, żeby chronić przyrodę ${ }^{11}$ a więc przybliżyć się do zrealizowania celu dialogu.

dług Jana Pawła II - oddaniem czci Bogu, więc formą modlitwy uwielbienia”. S. JAROMI, Boska Ziemia, Kraków 2019, s. 157. Zob. również: A. WAJDA, W trosce o Matkę Ziemię. Zarys biblijnego tła encykliki Laudato si, „Verbum Vitae” 31 (2017), s. 250,

6 Zob. LS 67.

7 Por. LS 124.

8 Zob. LS 42.

9 O potocznym i dosłownym rozumieniu ekologii zob.: M. Wyrostkiewicz, Osoba i środowisko. Studia teologiczno-ekologiczne, Lublin 2019, s. 27-38.

10 Por. LS 220.

11 Por. LS 19. 


\section{Kim jest partner dialogu?}

Idźmy dalej metaforą dialogu. Kiedy przygotowujemy się do argumentacji czy dialogu, konieczne jest nie tylko nasze dobre przygotowanie, ale też rozeznanie drugiej strony. Jeżeli nasz umysłowy konstrukt drugiej strony nie będzie się pokrywał z rzeczywistością, nasze argumenty mogą zostać niezrozumiane. Przygotowując się do rozmowy, zdajemy sobie sprawę, że inaczej będziemy przedstawiać sprawę obrony życia nienarodzonych zwolennikom aborcji, a inaczej jej radykalnym przeciwnikom. W dialogu musimy wiedzieć, kto jest kim. Rozmawiając z drugą osobą, poznajemy naszego rozmówcę, ale i on poznaje nas za pomocą kolejnych pytań i odpowiedzi: „w miarę jak dialog lub spór rozwija się, mówca coraz lepiej poznaje swojego partnera" ${ }^{12}$. W tym metaforycznie ujętym dialogu nie możemy posłużyć się tą metodą. Ogrom wiedzy o świecie stworzonym dostarczają nauki empiryczne, ale wydaje się, że w dialogu z przyrodą potrzebna jest nam również adekwatna antropologia i metafizyka.

W naukach empirycznych postęp jest stały i znaczny. Wiedza ta jest cenna i pozwala lepiej zrozumieć stworzenie. Poznanie stworzenia pozwala jeszcze bardziej się nim zachwycić. Odkrywamy, że inne gatunki są często bardziej podobne do człowieka, niż wcześniej można było przypuszczać, a nawet te zupełnie niepodobne posiadają zadziwiające właściwości. Naturalnym staje się też zobaczenie człowieka jako jedno ze zwierząt. Przez badania odkrywamy również, jak bardzo zły jest los stworzenia, zwłaszcza niektórych zwierząt zdanych na łaskę człowieka ${ }^{13}$. Ogromny postęp nauk wiąże się z tym, że badacze koncentrują się na niewielkich obszarach wiedzy. Specjalizacja wiedzy niesie ze sobą ryzyko jej fragmentaryzacji. Ogrodnik nie może skupiać się na jednej roślinie, lecz musi patrzeć na ogród integralnie - jako na całość ${ }^{14}$.

12 C. Perelman, Imperium retoryki. Retoryka i argumentacja, Warszawa, 2002, s. 28.

13 Zob. np. D. Probucka (red.), Etyczne potępienie myślistwa, Kraków 2020, lub pozycję pokazującą los zwierząt hodowanych przemysłowo: P. LyMBERY, I. OAKeshotT, Farmagedon. Rzeczywisty koszt taniego mięsa, tłum. R. Oślizło, Białystok 2015. Skrótowego przeglądu przypadków strasznego losu, jaki rodzaj ludzki zgotował stworzeniu dokonuje też papież Franciszek w encyklice Laudato si' w numerach 32-42.

14 Por. LS 138. 
Obok poznania stworzenia ważne jest również zrozumienie tego, kim jest człowiek. Tutaj mają znaczenie nie tylko nauki empiryczne, ale także - w myśli chrześcijańskiej - nauki filozoficzne. Franciszek zwraca uwagę, że człowiek musi znać swoje miejsce w stosunku do natury, zatem ma obowiązek siebie poznać ${ }^{15}$. Nieadekwatna antropologia i metafizyka prowadziły do dwóch, w pewnym sensie przeciwstawnych, błędów w rozpoznaniu partnera dialogu, na które zwraca uwagę m.in. papież Franciszek w Laudato si'. Pierwszym $\mathrm{z}$ nich jest tzw. skrajny antropocentryzm ${ }^{16}$. Można go definiować jako przekonanie, że człowiek jest czymś jakościowo zupełnie odmiennym od przyrody oraz że jest jej wyłącznym panem. W skrajnym antropocentryzmie miejsce Boga w pewnym sensie zajmuje człowiek, a przynajmniej rozum, nauka, postęp. Chociaż już na pierwszy rzut oka widać, że ubóstwienie człowieka nie ma nic wspólnego z chrześcijaństwem, skrajny antropocentryzm był z nim utożsamiany, ponieważ jego hasłem naczelnym jest zdanie: „Czyńcie sobie ziemię poddaną”, które zresztą można znaleźć w Biblii i to na samym początku (por. Rdz 1,28).

Wiele osób zatroskanych o ochronę przyrody obwinia o powstanie tego paradygmatu właśnie myśl chrześcijańską. Trzeba sobie jednak powiedzieć, że jest on sprzeczny z chrześcijańskim obrazem świata, gdyż obraz ten jest przede wszystkim teocentryczny ${ }^{17}$. Skąd się wziął? Możemy szukać jego źródeł w renesansie, kiedy to pojawiły się tendencje do „zapanowania nad przyrodą", lub u Kartezjusza, który wyraźnie wywyższył człowieka nad stworzenie ${ }^{18}$, albo w liberalizmie, który w kulcie wolności i realizacji pragnień widzi spełnienie człowieka ${ }^{19}$. W każdym razie jest to podejście bardzo złe, gdyż jego efektem jest degradacja świata, tak szybka, że żyjemy w ciągłym lęku. A także inne zjawiska, pozornie

15 Por. LS 115.

16 Papież Franciszek nie jest oczywiście odkrywcą tej koncepcji. Na skrajny antropocentryzm jako błędną podstawę zwracają zgodnie uwagę badacze z kręgu myśli chrześcijańskiej i spoza tego kręgu. Np. T. Ślipko nazywa go paradygmatem dominacji człowieka nad przyrodą i krytykuje. Por. T. ŚLIPKo, Bioetyka. Najważniejsze problemy, Kraków 2012, s. 36-40.

${ }^{17} \mathrm{Na}$ ten temat obszernie wypowiada się R. F. SADOwsKi, Filozoficzny spór o rolę chrześcijaństwa w kwestii ekologicznej, Warszawa 2015, s. 83-100.

${ }_{18}$ Za takim stanowiskiem wydaje się optować R. F. Sadowski. Por. tamże, s. 60-74.

19 To stanowisko T. Ślipko wyraża w: Bioetyka..., dz. cyt., s. 37. 
niezwiązane ze niszczeniem stworzenia: „wypaczony antropocentryzm stwarza przestrzeń dla wypaczonego stylu życia (...) kiedy istota ludzka stawia samą siebie w centrum, to w ostateczności da absolutny priorytet temu, co jest doraźnie wygodne, a cała reszta stanie się zbędna" ${ }^{20}$. Wielu chrześcijan żyje w tym duchu, konsumpcjonizmu i indywidualizmu, właściwe każdy z nas jest tym trochę nasiąknięty, dlatego też Franciszek wzywa wszystkich do nawrócenia. Jednak idea skrajnego antropocentryzmu nie jest źródłowo chrześcijańska.

Drugim, nie mniej poważnym błędem wynikającym z niezrozumienia, kim jest partner dialogu, jest biocentryzm ${ }^{21}$. Pozornie jest to spełnienie podstawowego postulatu dialogu, a nawet braterstwa, do którego wzywa nas papież Franciszek ${ }^{22}$ - wprowadzenie pewnej równości. $\mathrm{W}$ ujęciu biocentrycznym człowiek jest równy stworzeniu, jest kolejną jego częścią, a w skrajnych przypadkach nawet jest traktowany jako gatunek ekspansywny. Przyroda ma wartość wewnętrzną. To rodzi obowiązki nieniszczenia jej. Wszystkie organizmy mają równą wartość, co powoduje, że nie możemy preferować interesów ludzi. Niektórzy przedstawiciele biocentryzmu w trosce o przyrodę będą postulować zmniejszenie liczby ludzi. Biocentryzm, jako pogląd oparty na błędnej antropologii, Franciszek zdecydowanie odrzuca ${ }^{23}$.

Bardzo często w dyskursie publicznym pojawiają się próby utożsamienia ochrony przyrody z biocentryzmem ${ }^{24}$. Jest to pomyłka analogiczna do tej, którą popełniają ludzie przypisujący chrześcijaństwu skrajny antropocentryzm. Pomyłka, warto dodać, bardzo „wygodna”, ponieważ usprawiedliwia drwiny bądź obojętność, czy nawet wrogość wobec ochrony przyrody ${ }^{25}$. Troska o stworzenie, ochrona przyrody, wypływa

20 LS 122.

21 Zob. analizę A. Muszali w artykule: A. Muszala, Kwestie bioetyczne w encyklice Laudato si’ papieża Franciszka, „Polonia Sacra” 3 (2016), s. 51-52.

22 Por. LS 228.

23 Por. LS 118.

24 Por. P. De Plunkett, Ekologia. Stereotypy i rzeczywistość, tłum. S. Filipowicz, Poznań 2008, s. 281.

${ }_{25}$ Te właśnie postawy kwalifikuje papież Franciszek do nawrócenia ekologicznego. Por. LS 217. 
wprost z Biblii, jest obecna w nauczaniu społecznym Kościoła i w filozofii chrześcijańskiej. Jednak dla wielu ludzi, którzy nie są chrześcijanami (albo są, ale o tym nie myślą), troska o stworzenie może mieć inne źródło niż ubóstwienie przyrody, może mieć wyraz utylitarny - doskwiera im degradacja środowiska i coś z tym chcą zrobić, widzą w tym pewien interes, korzyść.

Antropologia chrześcijańska mówi o wyższości człowieka nad przyrodą. O jego niezbywalnej godności. Mówi jednak również o związku człowieka ze stworzeniem i o odpowiedzialności, jaką ma on podjąć ${ }^{26}$.

\section{Wynik dialogu - porozumienie}

Dialog powinien mieć swój wynik, pewne zrozumienie (funkcja majeutyczna), ale też wynikiem może być pewne porozumienie. Dlaczego porozumienie ze stworzeniem jest tak trudne? Bo uderza w nasze przyzwyczajenia, w to, co dla nas wygodne. Dziś dostajemy informację zwrotną od stworzenia. Jak pisze Franciszek, nasza siostra, tj. matka ziemia, „protestuje z powodu zła, jakie jej wyrządzamy nieodpowiedzialnym wykorzystywaniem i rabunkową eksploatacją dóbr"27. Chcemy wyciągnąć z ziemi więcej, niż może ona dać ${ }^{28}$ - wszyscy chcemy żyć jak Amerykanie, co oznacza, że potrzebowalibyśmy kilku takich planet, a to jest niemożliwe ${ }^{29}$ ! Jeżeli w dialogu ktoś protestuje lub krzyczy, to jest już bardzo źle, gdyż często może to znaczyć, że czuje z naszej strony zbyt wielką presję (ekologia powie - antropopresję, ludzki nacisk na ekosystemy, który jest dla nich degradujący). Chcąc kontynuować dialog, powinniśmy się z takiej presji wycofać. Zwłaszcza że - posłużmy się metaforą papieża Franciszka - ziemia jest jak nasza siostra ${ }^{30}$. Kto ma siostrę, ten wie, że można się z nią kłócić, ale też zawsze można się z nią dogadać. A nawet wypada nam pogodzić się z własną siostrą.

\footnotetext{
${ }^{26}$ Por. A. Muszala, Kwestie bioetyczne..., dz. cyt., s. 52-54.

27 LS 2.

28 Por. LS 106.

29 Por. LS 27.

${ }^{30}$ Por. LS 1-2.
} 
Jaka jest chrześcijańska propozycja porozumienia? Niezmienna od 2000 lat. Magisterium naucza tego, co zostało dane w objawieniu biblijnym, a jedynie przedstawia to w nowy sposób w szczególnych czasach, $\mathrm{w}$ jakich się znaleźliśmy ${ }^{31}$. Człowiek nie jest panem i posiadaczem natury, może jedynie z niej korzystać w ograniczonym stopniu. Jest też za stan natury odpowiedzialny, w tym za jej różnorodność. W końcu to jemu Bóg kazał nazywać wszystkie zwierzęta, a potem zabrać na arkę po parze $\mathrm{z}$ każdego gatunku, w tym tych zwierząt, o których myślimy z największym wstrętem. Człowiek jest też odpowiedzialny wobec kolejnych pokoleń, żadne bowiem nie otrzymało świata na własnośśc ${ }^{32}$. Człowiek jest przez Boga ściśle związany z otaczającym go światem, został ulepiony z gliny/roli i w proch się obróci! Dobro i zło urzeczywistnia się w tym świecie. Człowiek jest bytem wyjątkowym w przyrodzie, ale ta wyjątkowość nakłada na niego więcej praw niż obowiązków. Skoro człowiek jest bytem w przyrodzie, to i nim może zajmować się ekologia, zwłaszcza że jest gatunkiem dość dobrze poznanym. I ekologia integralna, którą promuje papież Franciszek, zajmuje się też człowiekiem - zwraca uwagę, że kryzys ekologiczny to kryzys człowieka i vice versa. W encyklice Centesimus annus św. Jan Paweł II wyraźnie wyeksplikował ten wyraz ludzkiej ekologii - tak samo jak i inne gatunki, człowiek musi mieć spełnione pewne warunki, żeby móc rozwijać się i prosperować. Papież wskazuje między innymi na środowisko rodzinne, ale wiemy też, że obcowanie ze stworzeniem jest elementem ludzkiej ekologii ${ }^{33}$. Papież Franciszek uszczegóławia to nauczanie swojego świętego poprzednika, wskazując m.in. na dostęp do mieszkań, odpowiednią jakość transportu publicznego, kwestię pracy, akceptację swojego ciała ${ }^{34}$, ale także może mniej oczywiste sprawy dla mieszkańców najzamożniejszych krajów - dostęp do wody ${ }^{35}$, pożywienia czy możliwość zachowania swojej odrębności kulturowej ${ }^{36}$.

\footnotetext{
31 Por. LS 17.

32 Por. A. Wajda, $W$ trosce o Matkę Ziemię..., dz. cyt., s. 251-252.

33 Por. Jan PaweŁ II, Encyklika Centesimus annus, Rzym 1991, 38-39.

${ }^{34}$ Por. LS 147-155.

35 Por. LS 26-31.

${ }^{36}$ Por. LS 143-146.
} 
Z tego wszystkiego płyną różne konkretne wskazania i - co warto podkreślać - w konkretach są one bardzo podobne do tego, o co apelują obrońcy przyrody niezwiązani $\mathrm{z}$ chrześcijaństwem, może $\mathrm{z}$ wyłączeniem radykałów. Zarazem są to postawy, które w chrześcijaństwie zawsze były cenione i propagowane - szacunek do stworzenia, pokora, życie w umiarze, ograniczenie konsumpcji, niezadawanie zbędnego cierpienia, wspieranie najuboższych, walka o sprawiedliwy świat dla wszystkich. W encyklice Laudato si' papież jest bardzo konkretny, wskazuje na szereg możliwych i czasem naprawdę drobnych wielkodusznych czynów wobec środowiska ${ }^{37}$, które gdy staną się nawykami, mogą mieć istotne znaczenie dla stworzenia, ale też i dla nas - jako droga cnoty - i dla innych, którzy mogą nas potraktować jako wzór. Za nauczaniem Kościoła podążają myśliciele i aktywiści - tworzone są różne inicjatywy w duchu ekologii integralnej ${ }^{38}$.

Niemal co trzeci człowiek na ziemi deklaruje się jako chrześcijanin, a niemal co piąty jako katolik, zatem potencjał do zmiany relacji człowiek - stworzenie u naturalnych odbiorców encykliki jest spory. A jednak dialog ze stworzeniem nie udaje się nam. Metafora dialogu wydaje się odsłaniać najważniejszą przyczynę: błąd w przygotowaniu charakterystyki uczestników dialogu. Być może tak bardzo zanurzeni jesteśmy w błędnej antropologii, w niechrześcijańskim życiu, że nie potrafimy zobaczyć ani tego, kim naprawdę jesteśmy, ani tego, co skutkiem działań człowieka dzieje się ze stworzeniem i jaki to ma wpływ na innych ludzi. Nie potrafimy zatem również dostrzec, że potrzebne jest nawrócenie ekologiczne. Niemniej na gruncie etyki, po ukazaniu się encykliki Laudato si', taką niewiedzę u katolików coraz trudniej traktować jako dającą się usprawiedliwić.

\footnotetext{
37 Por. LS 211.

38 Zob. np. S. JARomi, Boska ziemia, dz. cyt., s. 206-221.
} 


\section{Bibliografia}

Franciszek, Encyklika Laudato si', Rzym 2015.

Glinkowski W. P., Problem sceny $w$ Tischnerowskiej filozofii dramatu, „Analiza i Egzystencja” 34 (2016), s. 71-90.

Jan Paweł II, Encyklika Centesimus annus, Rzym 1991.

Jan Paweł II, Encyklika Redemptor hominis, Rzym 1979.

Jaromi S., Boska ziemia, Kraków 2019.

Lymbery P., Oakeshott I., Farmagedon. Rzeczywisty koszt taniego mięsa, tłum. R. Oślizło, Białystok 2015.

Muszala A., Kwestie bioetyczne w encyklice Laudato si’ papieża Franciszka, „Polonia Sacra" 3 (2016), s. 39-65.

Perelman C., Imperium retoryki. Retoryka i argumentacja, Warszawa 2002.

Plunkett P. de, Ekologia. Stereotypy i rzeczywistość, tłum. S. Filipowicz, Poznań 2008.

Probucka D. (red.), Etyczne potępienie myślistwa, Kraków 2020.

Sadowski R. F., Filozoficzny spór o rolę chrześcijaństwa $w$ kwestii ekologicznej, Warszawa 2015.

Ślipko T., Bioetyka. Najważniejsze problemy, Kraków 2012.

Wajda A., W trosce o Matke Ziemię. Zarys biblijnego tła encykliki Laudato si', „Verbum Vitae” 31 (2017), s. 241-266.

Walton D. N., The New Dialectic. Conversational contexts of argument, Toronto - Buffalo - London 1998.

Wyrostkiewicz M., Osoba i środowisko. Studia teologiczno-ekologiczne, Lublin 2019.

Dr Jakub Synowiec - wykładowca na Wydziale Filozofii Uniwersytetu Papieskiego Jana Pawła II w Krakowie. Jego główne zainteresowania badawcze to: metaetyka, argumentacja etyczna, efektywny altruizm, etyka Petera Singera, personalizm. Jest autorem kilkunastu artykułów oraz książki: Model argumentacji etycznej w etyce personalistycznej Karola Wojtyly i Tadeusza Stycznia (Kraków 2014). 